\title{
What do we know, not know, and need to know about ELT in Mexico?
}

\author{
¿Qué sabemos, no sabemos, y necesitamos saber sobre la enseñanza del inglés en México?
}

\author{
Paul Davies $^{a}$
}

\begin{abstract}
:
English Language Teaching (ELT) in Mexico covers a wide range of situations and results, from bilingual schools achieving excellent results, through language centres achieving generally good results, to common core English programmes in universities that start students at beginner level for the third or fourth time, after a decade or more of English classes at school, and generally fail to get most students beyond A2 level. Those common core university English programmes and other evidence suggest that most ELT in Mexico, especially school ELT, is failing to achieve worthwhile results. Sadly, we know too little for sure about both the successes and the failures of ELT in Mexico, though we can assume or guess a lot. This article considers what we really know about ELT in Mexico, what we do not know and urgently need to find out in order to radically improve the general situation, and how we might find it out.
\end{abstract}

Keywords:

English, teaching, ELT, success, failure, results, research

\section{Resumen:}

La enseñanza del inglés en México abarca una gama amplia de situaciones y resultados, desde escuelas bilingües que logran resultados excelentes, pasando por centros de lenguas que logran resultados en general buenos, hasta programas de inglés tipo tronco común en universidades que empiezan desde nivel principiante por tercera o cuarta vez, después de una década o más de clases de inglés en la escuela, y generalmente no llevan a la mayoría de los estudiantes más allá del nivel A2. Lamentablemente, sabemos muy poco a ciencia cierta sobre los éxitos y los fracasos de la enseñanza del inglés en México, aunque mucho podemos suponer o adivinar. Este artículo considera lo que realmente sabemos sobre la enseñanza del inglés en México, lo que no sabemos y necesitamos averiguar con urgencia para mejorar la situación general radicalmente, y cómo averiguarlo.

\section{Palabras Clave:}

Inglés, enseñanza, éxito, fracaso, resultados, investigación

\section{INTRODUCTION}

Like in most countries, there is top quality English language teaching in Mexico, along with good ELT, not so good ELT, and very poor ELT or ELT that achieves very poor results. An overview of ELT in a country may look mainly at whether the ELT is generally good, average or poor, as the case may be, and why. Where half or more than half of the adult population can use English for real communication, like in Greece, Germany, Sweden and the Netherlands (Eurobarometer, 2012)[1], it can be assumed that most or almost all of the ELT in schools is of high quality and is achieving good learning results. In Mexico, where only between about $10 \%$ and $15 \%$ of the adult population appear to be able to 'speak English' (11.6\% according to Consulta Mitofsky, 2012)[2], it can be assumed that most - over $85 \%$ - of the ELT in schools, and in higher education, is of low quality and is achieving very poor learning results.
It is curious that the Consulta Mitofsky survey referred to previously found that $11.6 \%$ of its sample of adult Mexicans could 'speak English' while around 10\% of basic education and $13.5 \%$ of all education from preschool to higher education in Mexico is private (SEP, 2017) [3] - a very close correlation between the percentage of adult English speakers and private education. It is curious but at least partly coincidental because we know that many people who went to private schools do not speak English and many that went to public schools do (though they may not have learnt much, or any, English at school but rather in higher education or in language centres). The word 'know' is in italics above to draw attention to it: We may know in the sense of being confident that the statement "many people who went to private schools do not speak English and many that went to public schools do" is true, but we do not know that from scientifically obtained data, only from our personal perception. Also, the reliability of the Consulta Mitofsky 
finding can be questioned: How large and representative of Mexico's adult population was the sample? How was the data obtained, through an English test or the question "¿Habla usted inglés?" What does 'speak English' mean, A2 level, B1, B2? And so on.

The first aim of this article, then, is to examine how much we really know about ELT in Mexico, and how much we can reasonably assume. It goes on to consider what we do not know, especially what we do not know and urgently need to if the generally poor ELT situation in Mexico is to be understood and significantly improved. Finally, it will consider how we might best find out that information.

\section{WHAT DO WE KNOW ABOUT ELT IN MEXICO?}

In this article so far, the following has been presented as what we know or can reasonably assume about ELT in Mexico:

A. Some ELT in Mexico produces substantial learning of English and contributes to the percentage of adult Mexicans, perhaps around $12 \%$, who can communicate in English.

B. Most ELT in Mexico, perhaps over 85\%, fails to produce much, or any, substantial learning of English.

Let us look first at evidence related to proposition $\mathrm{A}$, and then at evidence related to proposition $\mathrm{B}$.

Substantial teaching and learning of English in Mexico, about as good as any around the world, goes back a long way. It was, and is, where you would expect to find it: In bilingual schools and a few other schools that pay special attention to English, in American and British bi-national centres and other good language centres, and in the classes of a few outstanding English teachers, some of them teaching private classes.

The American School in Mexico City has its roots in the $19^{\text {th }}$ century, and the current American School Association was founded in 1921. The American school in Guadalajara started at the beginning of the $20^{\text {th }}$ century, and was closed down in 1934 and reopened in 1936. Both those schools started as 'American schools in Mexico', teaching entirely in English and with almost all students American or international, but they later became what they are today, Spanish-English bilingual schools with mostly Mexican students and teachers. The American School in Puebla opened as such in 1942. The old est major British school in Mexico, Greengates, was founded in 1951. There are many other well-established Mexican bilingual schools, doing very effective bilingual teaching, as well as other schools doing effective 'value-added ELT', that is, ELT of high quality, with more than the minimum hours of class recommended by the Secretaría de Educación Pública, and usually with many members of the non-ELT school staff knowing English well.

The two major bi-national centres in Mexico in the second half of the $20^{\text {th }}$ century were the Instituto Mexicano Norteamericano de Relaciones Culturales (commonly known as Relaciones Culturales), founded in 1942, and the Instituto Anglo Mexicano de Cultura (commonly known as The Anglo), founded in 1944. While cultural relations was the main focus of their missions, ELT was their main activity, and they were among the best, if not the best, practitioners of ELT in their time, which continues for the Anglo (now part of The Anglo Mexican Foundation), though Relaciones Culturales closed down in the 1990s. There were other ELT centres, but those two were large (over 60,000 students between them by the end of the 1970s) and dominant. One indication of their ELT expertise is that they both developed EFL textbooks that were sold internationally: The Anglo staff produced Active Context English, on Situational Language Teaching lines, published by Macmillan in 1971, and Relaciones Culturales staff produced In Touch, one of the world's first Notional-Functional textbooks, published by Longman in 1980. Members or ex-members of staff of both institutes have published literally hundreds of EFL textbooks with major publishers, both for use in Mexico and for international use, as well as ELT methodology books. One prolific writer of ELT methodology books, including The Practice of English Language Teaching, is Jeremy Harmer, who worked in The Anglo for over a decade. The dominance of the two major bi-national centres began to weaken a little from the 1980 s on, with the opening of more and more very professional commercial ELT centres, or schools, and then public university language centres, open to the general public, whose teachers were, increasingly, graduates of the universities' own BAs (or Licenciaturas) in English Language Teaching or Applied Linguistics, which were also established in or after the 1980s. All those ELT centres were not good for the 'business side' of Relaciones Culturales (which closed down in the 1990s) or The Anglo, but they were, and are, good for Mexico and Mexicans who really want to learn English and can pay for classes.

So, we have that history and current panorama of bilingual schools and other schools known for their ELT and binational centres and other language centres known for their ELT as reliable knowledge about ELT in Mexico. We know they exist, that they have grown over the years, and that people pay good money for their ELT. That is presumably because their ELT is well worth the investment. The effectiveness of their ELT is also borne out by the number of students who take and pass EFL proficiency tests: The Anglo alone handles over 70,000 Cambridge English test candidates each year (Cambridge Assessment, 2019) [4]. Virtually all registered international English proficiency test centres are the type of institutions we have just looked at, those schools and language centres. We can safely assert that they account for a, if not the, major portion of the successful ELT in Mexico, but more reliable information about them and how they operate could be very useful. 
Let us now turn to proposition B: Most ELT in Mexico, perhaps over $85 \%$, fails to produce much, or any, substantial learning of English. We have the Consulta Mitofsky survey mentioned above, which puts the portion of the adult population of Mexico that can 'speak English' at 11.6\%. There is other evidence that the above percentage is probably fairly close to the reality, and that most ELT in Mexico really is failing badly.

In 2004, a study of the English of students entering nine different institutions of higher education in Mexico City reported that $76.1 \%$ of 4,690 students failed the basic section of a modified placement test (González, Vivaldo \& Castillo, 2004) [5], and without the students from two highly prestigious private institutions included in the study - Colegio de México and ITAM - failure of the basic section of the test was around $90 \%$. That sample is of students entering higher education, not the general population, which would obviously be far worse. In light of the González, Vivaldo \& Castillo study, Lemus, Durán,\& Martínez (2008) [6] looked at the English of students in the universities of Aguascalientes, Durango and Quintana Roo and concluded: "This study has revealed that the low level of competence in English with which students enter Institutions of Higher Education is not exclusive to one state or region but, rather, a problematic situation that the whole country faces".

More recently, Aquino, Núnez \& Corona (2017) [7] tested a sample of 629 3rd year public secondary students in a rather poor but rising area of the Mexico City conurbation, Ciudad Netzahuacóyotl. They found that $97.3 \%$ were at starter level, $1.1 \%$ at $\mathrm{A} 1$ level, $0.3 \%$ at $\mathrm{A} 2$ level, $1.3 \%$ at $\mathrm{B} 1$ level (which is the target level for all students completing lower secondary school in the Programa Nacional de Inglés, PRONI, currently in its eleventh year). In questionnaire-based surveys carried out among teachers in public lower secondary schools in the State of Tlaxcala (Davies \& Domínguez, 2019) [8] and in the State of Guanajuato (Lengeling \& Wilson, 2020) [9], a total of 42 teachers in 42 different schools in two different states, the teachers were asked for their estimates of percentages of students entering their school with 'some English'. 25 teachers $(60 \%)$ put it at $0-10 \%$ of students and only 3 teachers $(7 \%)$ put it at over $50 \%$ of students (note that, in PRONI, all students are supposed to enter lower secondary school with A2 level English, not just 'some English'). The teachers were also asked for their estimates of percentages of students leaving their public lower secondary with A2+ level English. 30 teachers $(71 \%)$ put it at $0-10 \%$ of students and no teacher put it at over $50 \%$ of students (remember that the PRONI target level is B1). The teachers were also asked for their opinion on how appropriate for the students in their school the English syllabuses and textbooks were. 17 teachers $(40 \%)$ considered them 'not at all appropriate', 14 (33\%) 'not very appropriate', and only $11(26 \%)$ 'fairly appropriate' or 'perfectly appropriate'.
Then there is information that we have about ELT in upper second ary school and higher education (apart from the 2004 and 2008 studies mentioned above). Though students are supposed to leave lower secondary school with B1 level English, public upper second ary schools continue to teach English from beginner level again. Most public, and many private, universities and institutions of higher education do the same again in their common core type programmes for students.

In short, over 50 years after English became a curricular subject in lower and upper secondary schools, over 30 years after most universities established something on the lines of a common core English programme, and over 10 years after the launch of PRONI, the national English programme that starts curricular English courses in last year of preschool, most ELT in Mexico seems to be failing badly. On the other hand, ELT in certain contexts, notably bilingual schools, schools with 'value-added' or 'extra' ELT, and language centres is succeeding, in some cases as well as anywhere in the world. That all appears to result in around 10$15 \%$ of the ELT in Mexico being a, or the, major contribution to the $10-15 \%$ of the adult population that 'speaks English' (other Mexican English speakers are, nod oubt, migrants returned from the USA, members of English speaking families, and so on people who have learnt English through immersion, not classes ). However, that apparent $10-15 \%$ to $90-85 \%$ divide between successful and failing ELT as well as English-speaking and nonEnglish-speaking Mexicans is impressionistic, based on what mixed evidence is available, not fully on scientifically obtained data. Also, there must be a large borderland between A, successful ELT and Mexicans who speak English, and B, failing ELT and Mexicans who do not speak English, that is, a large A-B area, where the weakest successful ELT is failing in some respects and where the strongest failing ELT is succeeding in some respects. We need much more reliable information about A, A-B and B, especially the last two.

\section{WHAT DO WE NOT KNOW AND URGENTLY NEED TO KNOW ABOUT ELT IN MEXICO?}

This section will consist largely of a list of questions, mostly about B and A-B, the ELT in Mexico that is clearly failing badly or is not succeeding as much as it could. The A, or successful, sector of ELT in Mexico is, as stated above, largely as good and successful as ELT as anywhere in the world, and it can look after itself perfectly well. Of course, sector A ELT benefits enormously from favourable contexts and conditions, which simply cannot be created in public schools and other public institutions, or even less privileged private ones, all around Mexico: Usually, most, if not all, of the staff in the institution speak English, not just the English teachers; most students have family members, acquaintances and fellow students who speak English well; the English courses, and most students, go up to and beyond intermediate levels; many 
students, from A2 level on, take and pass international proficiency tests like KET, PET, FCE and TOEFL; the groups almost always have fewer than 30 students, often fewer than 20; and so on. They are contexts and conditions similar to those in bilingual schools, other prestigious schools, and language centres all around the world, and similar also to conditions and contexts in public schools in the Netherlands and Sweden, where $90 \%$ and $85 \%$ of the adult population speaks English (Eurobarometer, 2012). It should be emphasised that such 'Dutch and Swedish' contexts and conditions simply cannot be created in public schools all around Mexico. It is also worth mentioning here, in relation to public schools, that Spanish is a major international language, giving access to much global information and communication, while Dutch and Swedish are not: Motivation for learning English is in the air in the Netherlands and Sweden, and not at all in Mexico, where the general expectation in the air is not learning English - except in privileged contexts like bilingual schools.

Below are some key questions about or related to ELT in sectors B and A-B, which include almost all public schools, many private ones, many common core type English programmes in institutions of higher education, among other places with ELT.

1. What really is the approximate percentage of the adult population of Mexico that has B1+ English (the CEFR Threshold Level)? The assumption in this article is that it is between 10 and $15 \%$, with Consulta Mitofsky putting it at $11.6 \%$ in 2012, but with the meaning of "speak English" unclear. There might be a big surprise waiting to be discovered here, either less than $10 \%$ or more than $15 \%$ having B1+ English, which is a difference of 4 million or more people. The percentages in different parts of Mexico, a large and varied country, might also be interesting: US vs. Guatemala border states, major urban vs. minor urbanrural areas, etc.

2. How did Mexicans with B1+ English learn it? This information could confirm, or modify, the assumption, or the guess, that most did so in what we have called sector A institutions in this article - bilingual schools, schools with 'value-added' ELT, language centres, etc. A reliable answer to this question might suggest, for example, the creation of 'value-added' ELT in public secondary schools in areas where English is most likely to be needed, such as US border cities, international tourist and vacation centres, major urban and business cities and conurbations. It might also suggest establishing SEP language centres and/or SEP vouchers for other language centres for young adults needing English when school ELT has failed them, as most of it seems to be doing now (Davies, 2009) [10].
3. What is the level of English of students leaving public primary schools (now with A2 as the PRONI target), leaving lower secondary schools (now with BI as the PRONI target)? Evidence is given above in this article, but it is thin and limited. The answers to this question, and other data from follow-up research, could contribute massively to the evaluation of PRONI, and to its development, modification or total redesign, perhaps shifting it up to start in late primary school, and working hard on coordinating and improving ELT in lower secondary school, upper secondary school, and, perhaps, language centres.

4. What is the level of English of students entering, and then graduating from, higher education (which is the sector of the population most needing English, as skilled and professional workers)? Evidence is given above in this article, but it is incomplete and some of it probably outdated. This knowledge would contribute massively to the evaluation of ELT where its results matter most: Competence in English among students in higher education and graduates. Put together with 2 above, it might redirect PRONI away from early age ELT to put more emphasis on improving ELT in secondary and higher education.

5. What impact is the professionalization of ELT in Mexico, especially in public institutions, having on the results of ELT, especially in public institutions? Since the 1980s, English teachers have been graduating in ever larger numbers from public and other Mexican universities, more and more have gone on to do MAs and PhDs, many in Australian, UK and US universities, and at the same time, teacher training colleges (Normales) have upgraded their preparation of English teachers, as have other institutions with English teacher training programmes, and more and more people have been taking Cambridge TKT, ICELT and other certificates. This should have notably improved ELT in Mexico in general, but there is little evidence of a positive impact on ELT results in general.

There is much more knowledge about and related to ELT in Mexico that could be useful or enlightening, but answers to those five questions should give us plenty to think about.

\section{HOW MIGHT WE BEST FIND OUT WHAT WE URGENTLY NEED TO KNOW ABOUT ELT IN MEXICO?}

The answer to that question is through research, of course, appropriate research. The professionalization of ELT in Mexico has produced a lot of research, for $\mathrm{BA}, \mathrm{MA}$ and $\mathrm{PhD}$ theses, and in the pursuit of professional publication, sometimes partly to satisfy the requirements of an employer, especially if that employer is a university. Unfortunately, little of that research 
seems to have been directed at answering the five questions above and similar questions, and we remain largely in scientific ignorance about key issues in ELT in Mexico. So let us look here at our five questions and how they might best be answered, providing us with the knowled ge we currently lack.

What really is the approximate percentage of the adult population of Mexico that has B1+ English (the CEFR Threshold Level)?

The Consulta Mitofksy survey was a contribution, and still an important one because it is virtually all we have (if you think the English First English Proficiency Index [EF EPI] has any relevance at all, see Marin) [11], but it is just a lone, small contribution that is fast fading into the past of a growing country. The SEP, a group of universities, or some other major player or group of players needs to take this on. The survey design could be on large-scale Eurobarometer lines. If it included statistics for distinctly different regions and types of place in Mexico, as suggested above, it might be even more illuminating.

How did Mexicans with B1+English learn it?

This could be covered within the survey suggested above, but it could also be a research project in itself, within a university or group of universities. For example, it could be carried out by an MA or PhD candidate as a thesis project, or part of one, either exploring the EFL learning experience of English speakers in the university, both students and staff, or as a study on the lines of González, Vivaldo \& Castillo, cited above. Note that it asked students just entering university where they had studied upper secondary school, and found one public upper secondary school producing better English speakers than one private one - the schools were run by the universities the students went on to. The information produced by this research might suggest not only ideas like those presented above (the creation of 'valueadded' ELT in public secondary schools in areas where English is most likely to be needed, and SEP language centres and/or vouchers for courses in existing language centres), but also further research into why some public schools are much more successful in ELT than others and, therefore, possible models for other schools.

What is the level of English of students leaving public primary schools (now with A2 as the PRONI target), and leaving lower secondary schools (now with Bl as the PRONI target)?

Again this is thesis research or publication research territory for people progressing to an $\mathrm{MA}$ or $\mathrm{PhD}$ or to recognised researcher status. However, it should also be a priority for the SEP, monitoring its own national English programme, PRONI. As stated above, this knowled ge could contribute massively to the evaluation of PRONI, and to its development, modification or total redesign.
What is the level of English of students entering, and then graduating from, higher education (which is the sector of the population most needing English, as skilled and professional workers)?

This is really central to the question of ELT and English speakers in Mexico: Students in and after graduation from higher education, and at least some vocational training, are the sector of a nation's population that actually needs English most. If there are insufficient English speakers in that professional and skilled work sector, it is very bad for the country and for many of the individual professionals and skilled workers. This area could be researched by universities and other institutions of higher education as a major and ongoing project, or system (with English tests for all, or a representative sample, of students entering and graduating), or again, it could be a thesis or research publication project. The data on students entering would reflect on the ELT in upper secondary schools, many of them belonging to the university the students go on to. Considering the great cost, financial and academic, to universities of failing ELT, it is surprising that universities have not long ago put their heads together, obtained the relevant data, and acted energetically upon it. Behind all the ELT in regular education is the SEP, one way or another, and it may be worth repeating that reliable information, if we had it, might almost force the redirection of PRONI away from early age ELT to put more emphasis on improving ELT results in second ary and higher education.

What impact is the professionalization of ELT in Mexico, especially in public institutions, having on the results of ELT, especially in public institutions?

The ELT profession in Mexico today is very different from 30 or 40 years ago. Universities and many other institutions, including the SEP, now have virtually only ELT staff with BAs in or related to ELT, and many with MAs and PhDs. Yet the results of most ELT do not seem to be that much better than 30 or 40 years ago. There are many reasons for that, beginning with the fact that we do not know very well or surely what the results of ELT were decades ago nor what they are now. There is no doubt in my mind that English teaching in many places in Mexico and by many individual teachers is distinctly better and more effective now. But, on the other hand, there is so much more ELT now, not just because of population growth, though that has been significant, but also because of a "rush to English" (Cummins \& Davidson, 2007), or a rush to much more ELT. A lot of the new or additional ELT seems to be bad, and a lot of the old ELT seems to continue to be bad, or ineffective at least. Why? Do most Mexicans neither need English nor want to put the necessary effort into learning it? Are the contexts and conditions too unfavourable for most ELT to succeed? Are there too many untrained or poorly trained English teachers, especially in the new, additional ELT in PRONI? Was PRONI from last year of preschool on the wrong 
way to go (see Rixon, 2013, for where to do early age ELT and when not to do it) [12], and coordination and improvement of ELT from lower second ary school through to higher education the way it should have gone? Probably all of that and more, but we cannot be sure without much more appropriate research.

\section{CONCLUSION}

There is a lot of urgent and fundamental research into ELT in Mexico for ELT professionals, especially those who have become mainly academics and researchers, to do, but apparently few are doing much, or any, of it. Instead, most seem to be locked into globalized ELT and the global academic Applied Linguistics community, doing research and writing articles on topics such as:

- Variations in pre-service EFL teachers' implicit theories of reading.

- ELT thesis writing and novice teacher researchers.

- Evaluation approaches for ELT training courses.

- Subgroups and their needs.

- Makerspaces as constructivist language enviroments.

- Writer-reader interaction in economics abstracts.

- Humor in ELT and the evasive second script.

- Students' reactions to teacher corrective feedback on oral production.

- Building communities of practice in a language situated learning setting.

- Developing and validating an English proficiency test.

- Strategies for elementary dyslexic students' English language learning.

Those are all the Mexican and Mexico-based researchers' topics in articles published in the last 12 numbers of MEXTESOL Journal (all the other articles, 3 or 4 times more than the above, were from the USA, Canada, Europe and A sia, but on similar types of topic-global, not specifically Mexican, topics). There is nothing wrong with those topics in themselves. Everyone has the right to research and write about whatever they want to and can get accepted as a thesis topic or published in a peer-reviewed journal in pursuance of their career path. There is nothing wrong with being or feeling part of the globalized ELT community. However, it is surely disheartening that so few Mexican or Mexico-based ELT researchers are looking into the immense amount of failing ELT in our country, as well as at the spots and patches of ELT light in public education that might be tunnels out of the massive dark hole that most Mexican ELT is in.

\section{REFERENCES}

[1] Eurobarometer. Special Eurobarometer 386: Europeans and their languages. European Commission. 2012: 21. Retrieved 31.01.2020 from

https:/ec.europa.eu/commfrontoffice/publicopinion/archives/ebs/ebs_3 86_en.pdf.

[2] Consulta Mitofsky. Mexicanos y los idiomas extranjeros. Consulta Mitofsky. $\quad$ Retrieved $\quad 31.01 .2020$ from www.totaluni.com/articulo/leer/mexicanos_y_los_idiomas_extranjeros _consulta_mitofsky\#prettyPhoto[iframes]/0/.

[3] SEP Principales cifras del sistema educativo nacional 2016-2017. Secretaría de Educación Pública. 2017. Retrieved 31.01.2020 from https://www.planeacion.sep.gob.mx/Doc/estadistica_e_indicadores/pri ncipales_cifras/principales_cifras_2016_2017_bolsillo.pdf

[4] Cambridge Assessment. Cambridge English explores Mexico. Cambridge Assessment. 2019. Retrieved 31.01.2020 from https://www.cambridgea ssessment.org.uk/blogs/cambridge-englishexplore-mexico/

[5] González Robles, R., Vivaldo Lima, J. \& Castillo Morales, A. Competencia lingüística en inglés de estudiantes de primer ingreso a las instituciones de educación superior del área metropolitana de la ciudad de México. ANUIES, UAM Iztapalapa.

[6] Lemus, M. A., Durán, K. \& Martínez, M. El nivel de inglés y su problemática en tres universidades de México geográficamente distantes. Memorias del IV foro nacional de estudios en lenguas (FONAEL). 2008: 243-250.

[7] Aquino, M. D., Núnez, D. M. \& Corona, E. Competencia Lingüística y Estándares de Desempeño en Estudiantes al Terminar la Educación Básica'. In XIV Congreso Nacional de Investigación Educativa, San Luis Potosí, 2017, COMIE. 2017. Retrieved 31.01.2020 from www.comie.org.mx/congreso/memoriaelectronica/v14/doc/1419.pdf.

[8] Davies, P. \& Domínguez, R. Teachers' perceptions of ELT in public secondary schools. In English language teaching in Latin America, May 2019 number. Retrieved 31.01.2020 from https://www.eltinla .org/elt-in-latin-a merica.

[9] Lengeling, M. \& Wilson, A. Teacher's perceptions of ELT in public secondary schools in the State of Guanajuato (and Tlaxcala). In English language teaching in Latin America, February 2020 number. Retrieved 31.01.202 from https://www.eltinla .org/elt-in-latin-a merica.

[10] Davies, P. Strategic management of ELT in public educational systems: Trying to reduce failure, increase success. In TESL-EJ. 2009; 12(3). Retrieved 31.01.2020 from https://www.teslej.org/wordpress/issues/volume13/ej51/ej51a2/.

[11] Marian, J. Why EF EPI isn't what you think. In Jakub Marin's language learning, science \& art. Retrieved 31.01 .2020 from https://jakubmarian.com/why-the-ef-epi-rankings-are-not-what-youthink/

[12] Rixon, S. Optimum age or optimum conditions? Issues related to the teaching of languages to primary age children. British Council. 2000. 